\title{
Chronic airflow limitation after inhalation of overheated cooking oil fumes
}

\author{
F.G. Simpson, P.W. Belfield and N.J. Cooke \\ Department of Respiratory Medicine, The General Infirmary at Leeds, UK.
}

\begin{abstract}
Summary: A patient who developed severe irreversible airways obstruction with features of bronchiolitis obliterans after exposure to fumes from overheated cooking oil is described.
\end{abstract}

\section{Introduction}

Inhalation burns or inhalation of toxic gases such as the oxides of nitrogen and sulphur, phosgene, ammonia and chlorine may result in the development of severe airflow limitation predominantly due to obliterative bronchiolitis (Epler \& Colby, 1983). We report a case in which severe airflow obstruction with features of obliterative bronchiolitis developed after inhalation of fumes from overheated cooking oil.

\section{Case report}

A 22 year old non-smoking white man with cerebral palsy associated with mild mental subnormality and frequent generalized epileptic seizures presented in April 1982 having suffered a grand mal fit whilst cooking. A chip-pan containing vegetable oil was on the stove and became overheated, filling the room with fumes though neither the oil nor anything else ignited. The patient was found in the fume-filled room after about $1 \mathrm{~h}$. On examination in hospital he was noted to have injected conjunctivae and a slightly reddened throat but there was no dyspnoea, or cyanosis. The chest was clinically clear and chest radiograph was normal. There was no history of any previous chest complaints or of aspiration during seizures. One week later he attended the Accident and Emergency Department complaining of dyspnoea but examination and the chest radiograph were again normal, peak expiratory flow rate (PEFR) was 380 litres/min and he was referred to the psychiatric department.

Two weeks after the inhalation of fumes he was admitted with severe dyspnoea associated with wheeze. He was cyanosed with pulsus paradoxicus of $20 \mathrm{mmHg}$, PEFR was 200 litres/min, chest radiograph

Correspondence: F.G. Simpson, M.D., M.R.C.P., Respiratory Medicine, Killingbeck Hospital, Leeds 14, UK. Accepted: 23 May 1985 was normal and arterial blood gas tensions on $35 \% \mathrm{O}_{2}$ were $\mathrm{PO}_{2} 7.9 \mathrm{kPa}, \mathrm{PCO}_{2} 5.4 \mathrm{kPa}$, with a pH of 7.43 . Despite intravenous aminophylline, nebulized salbutamol and ipratropium bromide, antibiotics and prednisolone (initially $40 \mathrm{mg} / \mathrm{d}$, then $100 \mathrm{mg} / \mathrm{d}$ ) he deteriorated over the following $10 \mathrm{~d}$. Arterial $\mathrm{PO}_{2}$ fell to $5.9 \mathrm{kPa}$ with $\mathrm{PCO}_{2} 8.8 \mathrm{kPa}$, and he was mechanically ventilated for $9 \mathrm{~d}$. Subsequently he has remained dyspnoeic with chronic wheeze and productive cough. Serial pulmonary function tests (Table I) show severe airways obstruction with reduced transfer factor for carbon monoxide. Total lung capacity is increased but lung volume accessible to a single inhalation of helium $\left[\mathrm{V}_{\mathrm{A}}\right]$ is markedly reduced, suggesting poor gas mixing in the lungs. Flow-volume loops were technically unsatisfactory because of the patient's mental state but suggested increasing airways obstruction at low lung volumes. No significant reversibility to beta ${ }_{2}$ agonists, or ipratropium bromide was found.

Values for total lung capacity (TLC) and residual volume (RV) in July 1982 were obtained by helium

Table I Respiratory function tests over $2 \mathrm{y}$ after inhalation of cooking oil fumes

\begin{tabular}{|c|c|c|c|c|}
\hline & Predicted & $\begin{array}{l}\text { July } \\
1982\end{array}$ & $\begin{array}{c}\text { March } \\
1983\end{array}$ & $\begin{array}{l}\text { May } \\
1984\end{array}$ \\
\hline PEFR (1/min) & 650 & 200 & - & 75 \\
\hline $\mathrm{FEV}_{1}(\mathrm{l})$ & 4.7 & 0.8 & 0.9 & 0.6 \\
\hline FVC (1) & 5.7 & 2.4 & 2.1 & 2.1 \\
\hline $\mathrm{FEV}_{1} / \mathrm{FVC}(\%)$ & 83 & 33 & 43 & 29 \\
\hline TLC (1) & 7.0 & $6.1 \dagger$ & $8.7^{*}$ & 8.5 \\
\hline$V_{A}(1)$ & 7.0 & - & 3.8 & 3.6 \\
\hline $\mathbf{R V}(1)$ & 1.3 & 3.7 & 6.6 & 6.6 \\
\hline RV/TLC (\%) & 19 & 61 & 76 & 78 \\
\hline $\begin{array}{l}\text { TLCO (mmol/ } \\
\mathrm{min} / \mathbf{k P a})\end{array}$ & 13.7 & 10.0 & 9.0 & 8.6 \\
\hline
\end{tabular}

† Helium rebreathing; ${ }^{*}$ Body plethysmograph.

The Fellowship of Postgraduate Medicine, 1985 
rebreathing and are probably under-estimates because of poor gas mixing. There was probably no real change in these values between 1982 and 1983, though by 1984 there seems to have been some deterioraton.

\section{Discussion}

There can be little doubt that inhalation of the cooking oil fumes caused the severe airflow limitation in this patient. Though there is no direct evidence from histology or bronchography to confirm that the predominant lesion is that of obliterative bronchiolitis the pattern of lung function tests with gas trapping and markedly uneven ventilation (as shown by the disparity between TLC and $\mathrm{V}_{\mathrm{A}}$ ) suggest that the small airways are abnormal, though large airway involvement is also certainly present.

Obliterative bronchiolitis may be seen after viral infections especially in children (Epler \& Colby, 1983), in association with collagen vascular disease (Geddes et al., 1977), associated with chronic bronchitis (Hogg et al., 1968), and rarely may be idiopathic (Turton et al., 1981). In adults, inhalation of toxic fumes is the most frequently recognized cause but the fumes from overheated vegetable oil consist mainly of vaporized glycerides and do not contain any of the toxic gases recognized as causing this syndrome (Smith, R.W., Scientific Services Branch, GLC, personal communication). There was no evidence of airway burns in this case or of any of the associations listed above.

The effects of fats and oils on the lungs after

\section{References}

EPLER, G.R. \& COLBY, T.V. (1983). The spectrum of bronchiolitis obliterans Chest, 83, 161 .

GEDDES, D.M., CORRIN, B., BREWERTON, D.A., DAVIES, R.J. \& TURNER-WARWICK, M. (1977). Progressive airway obliteration in adults and its association with rheumatoid disease. Quarterly Journal of Medicine, 46, 427.

HOGG, J.C., MACKLEM, P.T. \& THURLBECK, W.M. (1968). Site and nature of airway obstruction in chronic obstructive lung disease. New England Journal of Medicine, 278, 1355.

MILLER, G.J., ASHCROFT, M.T., BEADNELL, H.M.S.G., WAGNER, J.C. \& PEPYS, J. (1971). The lipoid pneumonia of injection into the trachea of animals were studied by Pinkerton (1928). On the whole, vegetable and mineral oils are relatively non-toxic whereas oils of animal origin cause severe inflammation and fibrosis. Perhaps of more relevance to this case, however, are observations on the chronic lipoid pneumonia seen in blackfat tobacco smokers in Guyana (Miller et al., 1971). Blackfat tobacco is impregnated with a light mineral oil (canopus oil) and petroleum jelly as flavouring. Chronic smoking of this tobacco produces a widespread pulmonary fibrosis with severe irreversible airways obstruction and increased residual volume without increase in total lung capacity. Histologically there is an interstitial fibrosis with lipid deposition in alveolar macrophages and with granuloma formation in severe cases. Interestingly, bronchiolitis obliterans may also be associated with interstitial infiltrates or fibrosis (Seggev et al., 1983).

It seems, therefore, that inhalation of the fumes of even non-toxic oils may cause severe lung damage. Domestic fires involving cooking oil are common and whilst brief exposure to fumes in this situation has not been reported to have long-term adverse effects we would suggest that patients exposed to such fumes for more than a few minutes should be carefully assessed.

\section{Acknowledgements}

We thank Dr R. Hainsworth for the pulmonary function test data and for helpful advice and Mrs K. Marsden for secretarial assistance. blackfat tobacco smokers in Guyana. Quarterly Journal of Medicine, 160, 457.

PINKERTON, H. (1928). The reaction to oils and fats in the lung. Archives of Pathology, 5, 380.

SEGGEV, J.S., MASON, U.G., WORTHEN, S., STANFORD, R.E. \& FERNANDEZ, E. (1983). Bronchiolitis obliterans. Report of three cases with detailed physiological studies. Chest, 83, 169.

TURTON, C.W., WILliaMS, G. \& GREEN, M. (1981). Cryptogenic obliterative bronchiolitis in adults. Thorax, 36, 805. 